\title{
Copper-catalyzed aziridination of allylglycine derivatives
}

\author{
Loïc Leman, Laurent Sanière, Philippe Dauban,* and Robert H. Dodd* \\ Institut de Chimie des Substances Naturelles, CNRS, Avenue de la Terrasse \\ 91198 Gif-sur-Yvette cedex, France \\ E-mail: philippe.dauban@icsn.cnrs-gif.fr and robert.dodd@icsn.cnrs-gif.fr
}

Dedicated to Professor A. Varvoglis on his $65^{\text {th }}$ birthday

(received 30 Jan 03; accepted 24 Mar 03; published on the web 07 May 03)

\begin{abstract}
The copper-catalyzed and iodosylbenzene-mediated aziridination of (S)-N-(9phenylfluorenyl)allylglycine tert-butyl ester $\mathbf{1 0}$ led to the isolation of the corresponding aziridine 13 in $28 \%$ yield $(65 \%$ based on consumed starting material). The $(2 S, 4 S)$ isomer was preferentially formed with a diastereomeric excess of $36 \%$.
\end{abstract}

Keywords: Allylglycine, aziridine, aziridination, copper catalyst, iminoiodane

\section{Introduction}

Iodosylbenzene $\mathrm{PhI}=\mathrm{O} 1$ was one of the first hypervalent iodine reagents ever to be prepared. Discovered at the end of the $19^{\text {th }}$ century by Willgerodt, ${ }^{1}$ this stable yellow solid, easily accessible by base treatment of commercially available $\mathrm{PhI}(\mathrm{OAc})_{2},{ }^{2}$ has since been used, among other purposes, for the synthesis of epoxides via the metal-catalyzed oxygen atom transfer to alkenes (equation 1). ${ }^{3}$

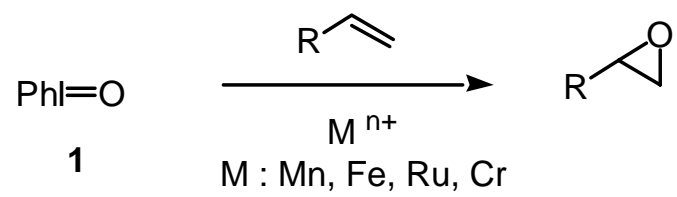

Equation 1. Metal-catalyzed epoxidation of olefins mediated by iodosylbenzene.

By contrast, the aza-analogues of 1, i.e. the iminoiodanes or the iodonium imides of general formula $\mathrm{ArI}=\mathrm{NSO}_{2} \mathrm{R}$, remained unknown until their preparation was described in the mid 70's by Abramovitch ${ }^{4}$ and, particularly, by Yamada. ${ }^{5}$ Nearly two more decades were necessary before these reagents were shown to be synthetically useful for $\mathrm{C}-\mathrm{N}$ bond formation. By employing a catalytic quantity of copper(I) or (II) salts, Evans demonstrated that $[N-(p-$ toluenesulfonyl)imino]phenyliodane $(\mathrm{PhI}=\mathrm{NTs})$ reacts with olefins to give the corresponding 
aziridines. $^{6}$ This reaction thus represents a standard method for the preparation of this synthetically useful three-membered ring heterocycle. ${ }^{7}$ However, the troublesome preparation of the iminoiodanes have a strong negative influence on the efficiency of the nitrene transfer which has hampered a wider application of this aziridination process in organic synthesis. That is why we felt it necessary to circumvent this problem by developing a one pot process that allows a direct copper-catalyzed nitrogen atom transfer onto olefins without isolation of these useful but capricious reagents. This led to our unexpected discovery that such transfer could be mediated by iodosylbenzene itself (equation 2$)^{8}{ }^{8}$

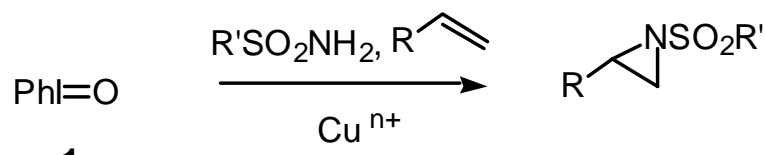

1

Equation 2. Copper-catalyzed aziridination of olefins mediated by iodosylbenzene.

With this methodology in hand, we investigated its application to the total synthesis of nitrogen-containing natural products. We thus chose enduracididine 2 as the first synthetic target (scheme 1). This $\alpha$-amino acid was isolated in 1968 from Streptomyces fungicidicus as a constituent of the peptide antibiotic enduracidin. ${ }^{9}$ To our knowledge, only one preparation of this compound is found in the literature and is based on the chemical degradation of the imidazole ring of histidine. ${ }^{10}$

A retrosynthetic analysis led us to consider the 1,2-diamino moiety of 3 as a possible precursor of the cyclic guanidine of 2 . Such a derivative could be formed via ring-opening by a suitable nitrogen nucleophile of the aziridine 4, the latter being the product expected from the application of the copper-catalyzed aziridination of a suitably protected allylglycine derivative.

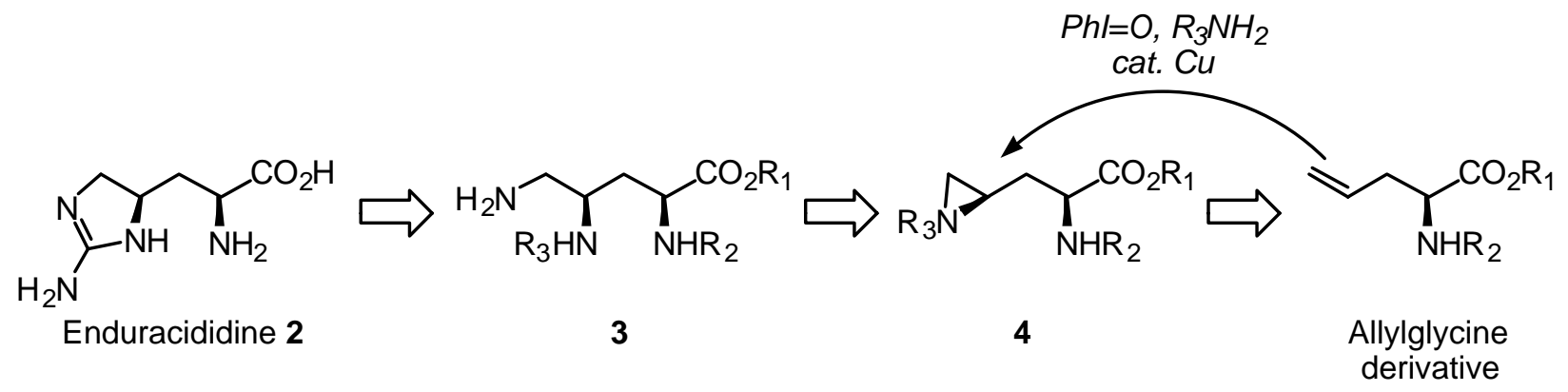

Scheme 1. Retrosynthetic analysis of enduracididine.

Of particular interest was the study of this copper-catalyzed atom transfer onto a nitrogencontaining olefinic substrate since no such example has ever been reported in the literature. In this report, we wish to present our results obtained in this field. 


\section{Results and Discussion}

Our first investigations were aimed at determining the suitable protecting groups of the amino acid function of allylglycine. Conscious of the affinity of copper for nitrogen ligands, we speculated that the amino function of allylglycine derivatives could interact with copper catalysts and therefore diminish the efficiency of the nitrene transfer. In this context, we first studied the effect of the nature of the amino protecting group on the course of the copper-catalyzed aziridination. Both enantiomers of allylglycine could be obtained by enzymatic resolution of ethyl $N$-(tert-butoxycarbonyl)allylglycinate 5 with $\alpha$-chymotrypsine (scheme 2 ). ${ }^{11}$ The resulting acid 6 and ester 7 were then transformed into compounds 8-12 by standard sequences of deprotection-protection reactions.

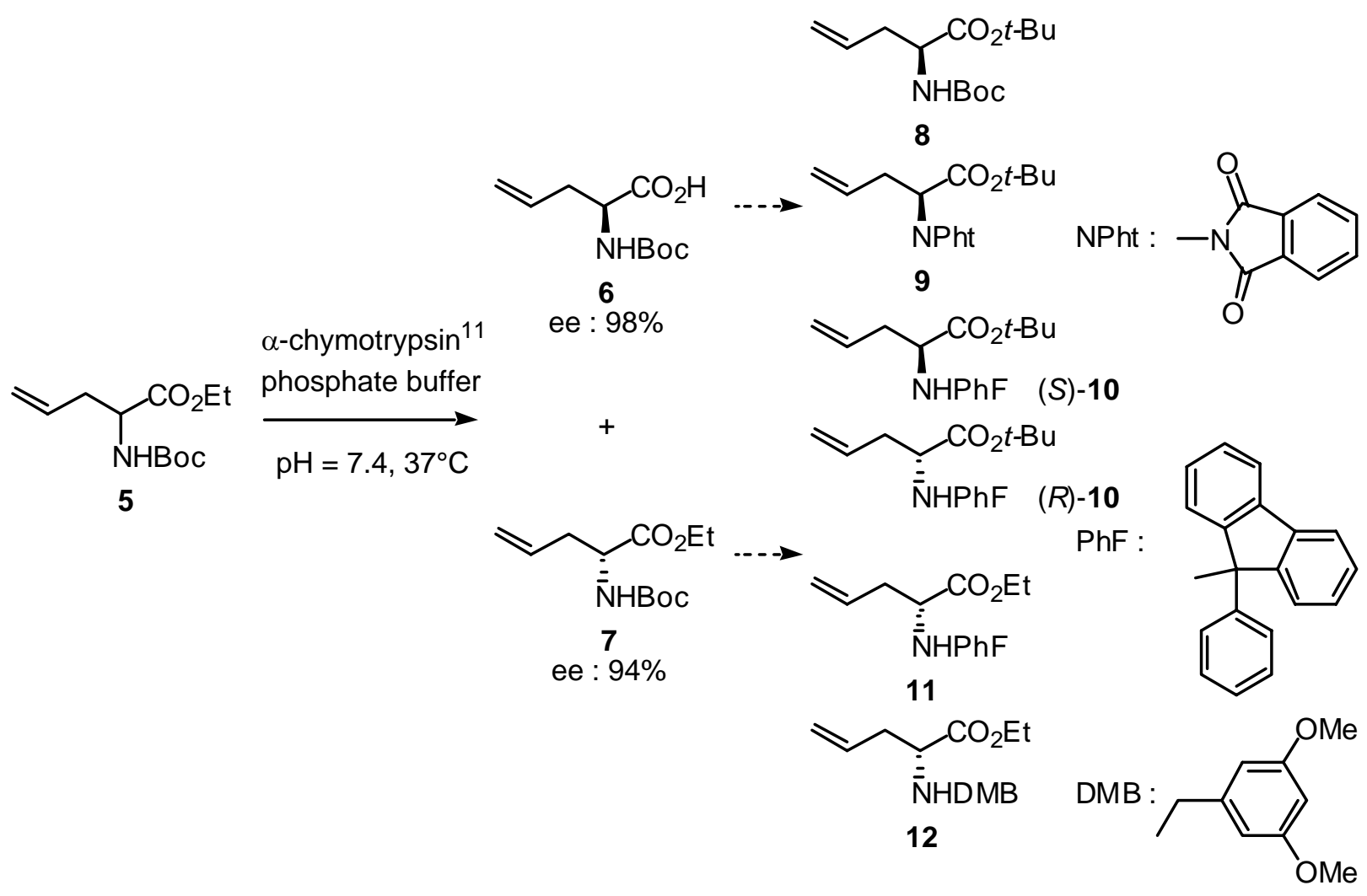

Scheme 2. Allylglycine derivatives.

Copper-catalyzed aziridination was then applied to all these substrates. In preliminary experiments, use of in situ generated $\mathrm{PhI}=\mathrm{NSes}^{12}$ (Ses : $\mathrm{SO}_{2} \mathrm{CH}_{2} \mathrm{CH}_{2} \mathrm{SiMe}_{3}$ ) was found to give better results than $\mathrm{PhI}=\mathrm{NTs}$ but equivalent results to the $p$-nitrobenzenesulfonamide derived iminoiodane $\mathrm{PhI}=\mathrm{NNs} .{ }^{13}$ Several copper complexes were also tested and among those, copper (I) salts appeared to be the more efficient. ${ }^{14}$ Thus, typical experiments were run with iodosylbenzene and $\mathrm{SesNH}_{2}$ added portionwise over a period of 90 minutes, in the presence of $25 \mathrm{~mol} \%$ of $\mathrm{Cu}\left(\mathrm{CH}_{3} \mathrm{CN}\right)_{4} \mathrm{PF}_{6}$ in acetonitrile at room temperature. Results are listed in table 1. 
Table 1. Copper-catalyzed aziridination of compounds 8-12

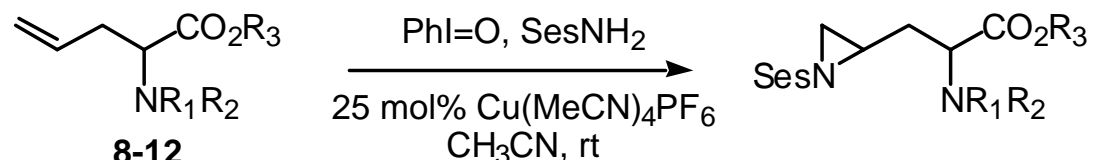

8-12

$$
\mathrm{CH}_{3} \mathrm{CN} \text {, rt }
$$

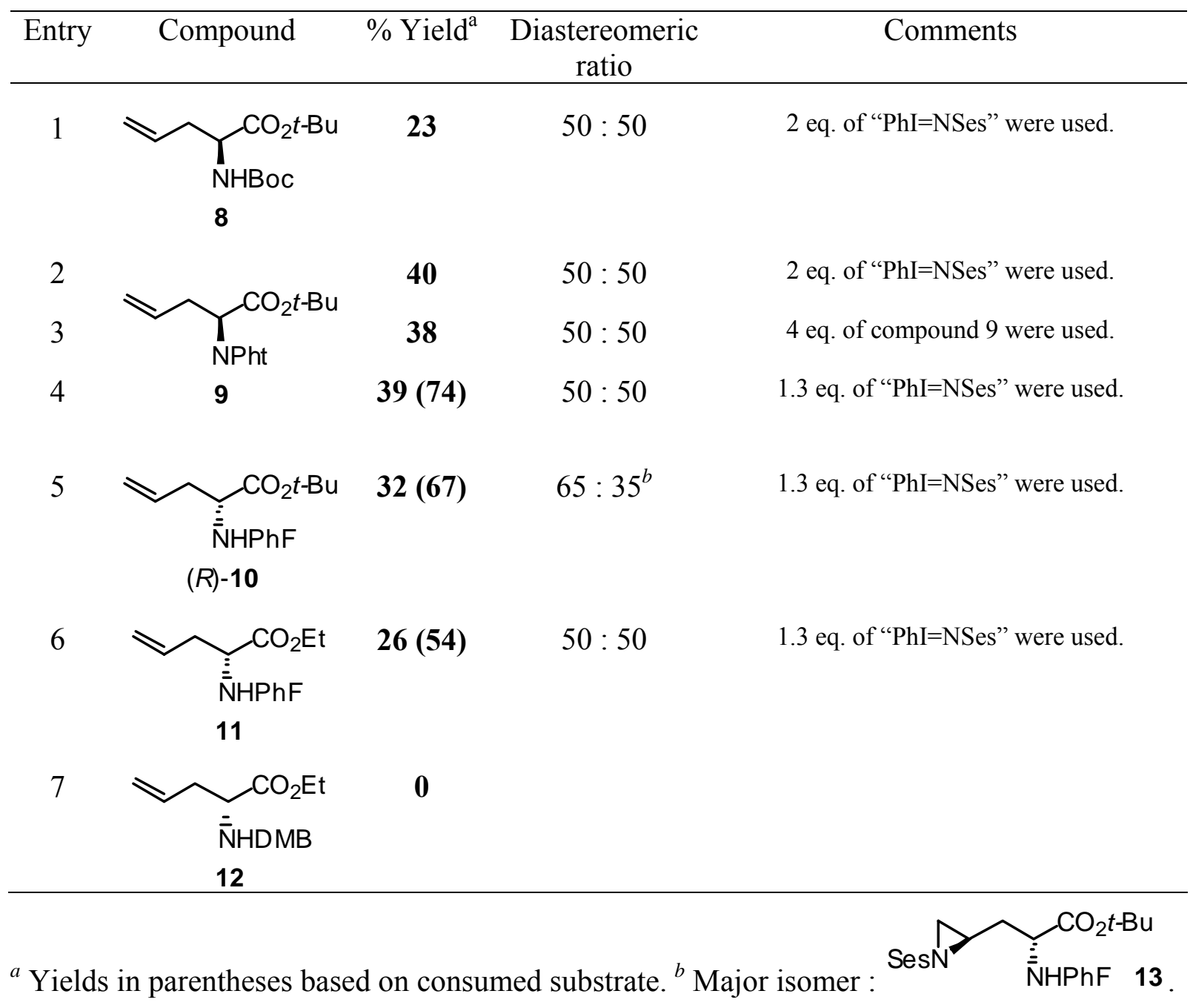

Of the four different protecting groups of the nitrogen function, the phthalimide gave the highest yields (entries 2, 3 and 4). The $N$-Boc derivative 8 (entry 1) afforded the corresponding aziridine in low yield while the presence of an $N$-dimethoxybenzyl group (entry 7 ) totally inhibited the nitrene transfer. In the latter case, a possible explanation lies in the interaction between this electron-rich arene ring and the hypervalent iodine reagent. ${ }^{15}$ In order to improve these modest yields, the relative amounts of olefin 9 and generated iminoiodane $\mathrm{PhI}=\mathrm{NSes}$ were varied. However, use of an excess of allylglycine derivative 9 (entry 3) or of PhI=NSes (entry 2) did not influence the efficiency of the process. Thus, nearly stoichiometric conditions (entry 4) seem to be optimal, allowing formation of the corresponding aziridine in $39 \%$ isolated yield 
(74\% yield based on substrate consumed). The ease of separation of product and substrate by chromatography on silica gel makes this procedure nevertheless acceptable.

It may be noted from table 1 that in all the precedent cases, no diastereoselectivity was observed in the formation of the aziridine. In contrast, the presence of the bulky phenylfluorenyl group led to formation of $(2 R, 4 R) 13$ as the major isomer with a diastereomeric excess of $30 \%$ albeit with a slightly lower overall yield of 32\% (67\% yield based on substrate consumed, entry 5). It is worth mentioning the additional influence of the tert-butyl ester since its replacement by an ethyl ester led to a complete loss of selectivity (entry 6). As a result of this study, we decided to conduct further investigations on the allylglycine derivative 10.

In particular, we turned our attention to the effects of other reaction parameters, such as solvent, temperature and quantities of catalyst, on yields and diastereoselectivities. Results are shown in table 2.

Table 2. Copper-catalyzed aziridination of compound $(R)-10$

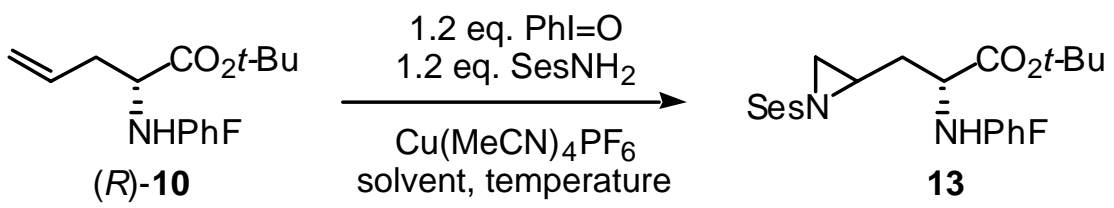

\begin{tabular}{cccccc}
\hline Entry & $\mathrm{Cu}\left(\mathrm{CH}_{3} \mathrm{CN}\right)_{4} \mathrm{PF}_{6}$ & Solvent & Temperature & \% Yield & $\begin{array}{c}\text { Diastereomeric ratio } \\
(\mathrm{R}, \mathrm{R}):(\mathrm{R}, \mathrm{S})\end{array}$ \\
\hline 1 & $25 \mathrm{~mol} \%$ & $\mathrm{CH}_{3} \mathrm{CN}$ & $\mathrm{rt}$ & $\mathbf{3 2}(\mathbf{6 7})$ & $65: 35$ \\
2 & $25 \mathrm{~mol} \%$ & $\mathrm{C}_{6} \mathrm{H}_{6}$ & $\mathrm{rt}$ & $\mathbf{2 6}(\mathbf{4 5})$ & $67: 33$ \\
3 & $25 \mathrm{~mol} \%$ & $\mathrm{CH}_{2} \mathrm{Cl}_{2}$ & $\mathrm{rt}$ & $\mathbf{2 4}(\mathbf{4 4})$ & $70: 30$ \\
4 & $25 \mathrm{~mol} \%$ & $\mathrm{CH}_{3} \mathrm{CN}$ & $5^{\circ} \mathrm{C}$ & $\mathbf{3 0}(\mathbf{7 4})$ & $63: 37$ \\
5 & $25 \mathrm{~mol} \%$ & $\mathrm{CH}_{3} \mathrm{CN}$ & $45^{\circ} \mathrm{C}$ & $\mathbf{2 5}(\mathbf{5 3})$ & $67: 33$ \\
6 & $50 \mathrm{~mol} \%$ & $\mathrm{CH}_{3} \mathrm{CN}$ & $\mathrm{rt}$ & $\mathbf{2 8}(\mathbf{6 0})$ & $66: 34$ \\
7 & $100 \mathrm{~mol} \%$ & $\mathrm{CH}_{3} \mathrm{CN}$ & $\mathrm{rt}$ & $<\mathbf{1 5}$ & \\
\hline
\end{tabular}

${ }^{a}$ Yields in parentheses based on consumed substrate.

Disappointingly, none of the modifications of the initial reaction conditions (entry 1) led to improved nitrene transfer efficiency. Use of benzene (entry 2) or dichloromethane (entry 3 ) as the solvent gave slightly lower yields as was the case of higher reaction temperature (entry 5), 
while an overnight reaction at $5^{\circ} \mathrm{C}$ (entry 4$)$ presented no advantage. Since the starting material was always recovered in significant amounts, these invariably modest yields could be explained by the previously observed weak reactivity of a terminal unsubstituted double bond towards iodanes. $^{12}$ More unexpected were the results obtained by changing the mol\% of copper complexes, higher quantities of catalyst leading to a substantial decrease in aziridine formation (entries 1,6 and 7). No rational explanation can be proposed to account for the poor catalytic activity of the copper salt in these reactions. ${ }^{16}$

In all cases, the $(2 R, 4 R)$ isomer of aziridine 13 was always isolated with a diastereomeric excess in the $32-40 \%$ range. In order to improve this diastereoselectivity, asymmetric coppercatalyzed aziridination was performed in the presence of chiral bis(oxazolines). ${ }^{17}$ Among the ligands tested, the tert-butyl derivative 14 appeared to give the highest excess (d.e. $=50 \%$ ) when the reaction was run at $-20^{\circ} \mathrm{C}$ (scheme 3). This gain in selectivity was, however, offset by a lowered reactivity since the aziridine was isolated with a yield of only $16 \%$.

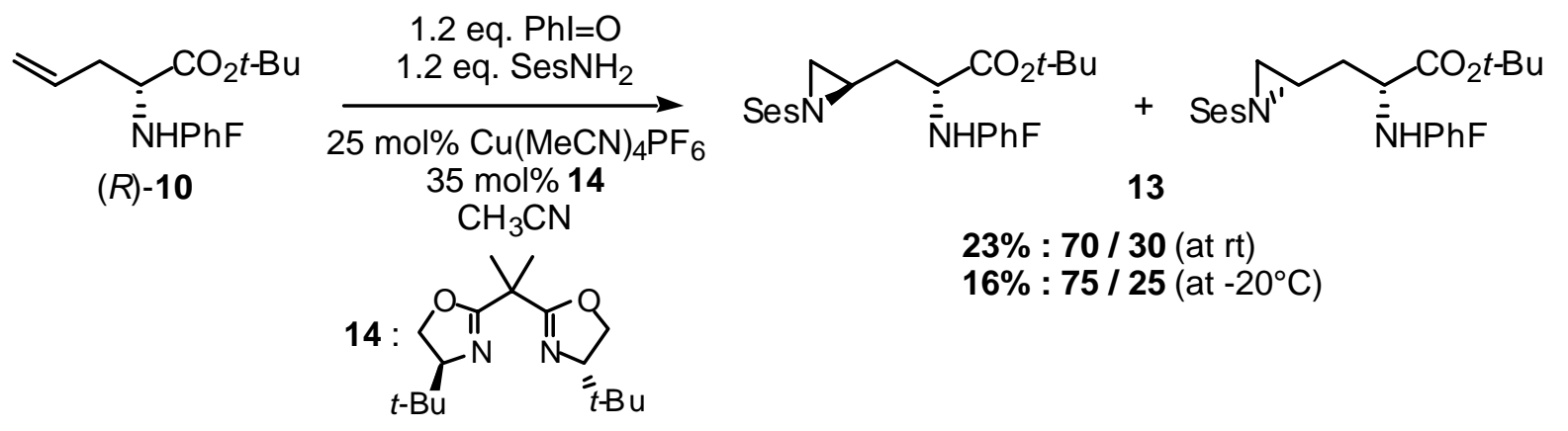

Scheme 3. Asymmetric copper-catalyzed aziridination of allylglycine derivative 10 .

In the context of the total synthesis of enduracididine, aziridination of the $(S)$-enantiomer of allylglycine 10 was carried out on a $2.5 \mathrm{~g}$-scale using the optimized conditions of table 2 , entry 1 . While $57 \%$ starting material was recovered, $0.95 \mathrm{~g}(28 \%$ or $65 \%$ conversion $)$ of the $\mathrm{N}$ (Ses)aziridine was obtained with a diastereomeric ratio of $68: 32$ in favor of the $(2 S, 4 S)$ isomer, as determined by HPLC on a chiral column.

In conclusion, the presently described copper-catalyzed aziridination of allylglycine derivatives is the first example of the application of this metal-catalyzed nitrene transfer to a nitrogen-containing substrate. The modest yields observed appear to be mainly related to the low reactivity of unsubstituted terminal olefins in general. However, it is not clear whether or not the nitrogen atom of the substrate has an influence on the course of the reaction. This study therefore clearly demonstrates the need for further investigations of metal-catalyzed aziridinations of olefins in order to improve its scope. In the case of allylglycine, the process gives rise to highly functionalized molecules which should prove useful for the preparation of natural and/or biologically active compounds. 


\section{Experimental Section}

General Procedures. ${ }^{1} \mathrm{H}$ and ${ }^{13} \mathrm{C}$ NMR chemical shifts are given as $\delta$ values with reference to $\mathrm{Me}_{4} \mathrm{Si}$ as internal standard. Thin-layer chromatography was performed on Merck silica gel 60 plates with a fluorescent indicator. The plates were visualized with UV light (254 nm) and with a solution of phosphomolybdic acid (25 g) and cerium sulfate $(10 \mathrm{~g})$ in concentrated sulfuric acid $(60 \mathrm{~mL})$ and water $(940 \mathrm{~mL})$. All column chromatography was conducted on 60 silica gel (230$240 \mathrm{mesh})$ at medium pressure (200 mbar). All solvents were distilled and stored over $4 \AA$ molecular sieves before use. Elemental analyses were performed at the ICSN, CNRS, Gif-surYvette, France.

(S)-tert-Butyl 2-N-(9-phenyl-9H-fluoren-9-yl)amino-4-pentenoate (10). A suspension of carboxylic acid $6(32 \mathrm{~g}, 0.149 \mathrm{~mol})$ in $6 \mathrm{~N}$ hydrochloric acid $(1.725 \mathrm{~L})$ was heated under reflux for 17 $\mathrm{h}$ and then, after cooling to $\mathrm{rt}$, was evaporated to dryness under vacuum. To the resulting white solid was successively added tert-butyl acetate $(0.975 \mathrm{~L})$ and, carefully at $0^{\circ} \mathrm{C}$ under argon, a solution of $65 \%$ perchloric acid $(15.6 \mathrm{~mL}, 1.1 \mathrm{eq}$.$) . After 48 \mathrm{~h}$ of stirring at $\mathrm{rt}$, the reaction mixture was diluted with ethyl acetate $(500 \mathrm{~mL})$ and extracted three times by a solution of $10 \%$ citric acid. The aqueous phase was cooled to $0^{\circ} \mathrm{C}$ before being made basic ( $\mathrm{pH} 10$ ) by slow addition of sodium hydrogenocarbonate and then potassium carbonate. The resulting aqueous phase was extracted with ethyl acetate. The organic extracts were combined, dried over sodium sulfate and evaporated to dryness without heating to afford a colorless oil (14.3 g, $0.0835 \mathrm{~mol}$, $56 \%$ ) that was used in the following step without further purification. Selected data : ${ }^{18} \mathrm{H}$ NMR $\left(\mathrm{CDCl}_{3}, 250 \mathrm{MHz}\right) \delta 1.47(\mathrm{~s}, 9 \mathrm{H}), 1.82($ broad s, 2H), 2.3-2.55 (m, 2H), $3.46(\mathrm{dd}, 1 \mathrm{H}, J=5.2$, $6.9 \mathrm{~Hz}), 5.1-5.2(\mathrm{~m}, 2 \mathrm{H}), 5.65-5.85(\mathrm{~m}, 1 \mathrm{H}) ;{ }^{13} \mathrm{C} \mathrm{NMR}\left(\mathrm{CDCl}_{3}, 75 \mathrm{MHz}\right) \delta 28.1,39.2,54.2$, 81.2, 118.6, 133.5, 174.4; ESMS m/z $194\left[\mathrm{M}+\mathrm{Na}^{+}\right], 172\left[\mathrm{M}+\mathrm{H}^{+}\right]$.

To a solution of the so-prepared $(S)$-tert-butyl 2-amino-4-pentenoate $(14.3 \mathrm{~g}, 0.0835 \mathrm{~mol})$ in nitromethane $(0.275 \mathrm{~L})$ were successively added potassium phosphate (38 g, 2 eq.) and 9-bromo9-phenylfluorene (29.4 g, 1.1 eq.). After 3 days of stirring at rt, the reaction mixture was diluted with ethyl acetate, filtered and the filtrate was evaporated to dryness. The resulting oily residue was purified by flash chromatography on silica gel (heptane-ethyl acetate 95:5) to afford compound 10 (13.0 g, $31.6 \mathrm{mmol}, 38 \%$ ) as a colorless oil. [ $\alpha]_{D}^{21}-173^{\circ}$ (c 1.13, $\left.\mathrm{CHCl}_{3}\right) ;{ }^{1} \mathrm{H} \mathrm{NMR}$ $\left(\mathrm{CDCl}_{3}, 250 \mathrm{MHz}\right) \delta 1.22(\mathrm{~s}, 9 \mathrm{H}), 2.2-2.3(\mathrm{~m}, 2 \mathrm{H}), 2.71(\mathrm{t}, 1 \mathrm{H}, J=5.8 \mathrm{~Hz}), 3.12$ (broad s, 1H), 5.0-5.1 (m, 2H), 5.7-5.9 (m, 1H), 7.2-7.5 (m, 11H), 7.7-7.8 (m, 2H) ; ${ }^{13} \mathrm{C} \mathrm{NMR}\left(\mathrm{CDCl}_{3}, 75\right.$ $\mathrm{MHz}) \delta 28.1,40.4,56.0,73.2,80.7,117.3,119.9,125.5,126.3,127.2,127.9,128.3,134.7$, 140.3, 141.0, 145.1, 149.5, 174.6; IR (film) v 3312, 2977, 1724, 1448, 1367, 1154, 746, $733 \mathrm{~cm}^{-}$

${ }^{1}$; ESMS m/z 434 [M+Na ${ }^{+}$. Anal. Calcd for $\mathrm{C}_{28} \mathrm{H}_{29} \mathrm{NO}_{2}: \mathrm{C}, 81.72 ; \mathrm{H}, 7.10$; N, 3.40. Found: C, 81.99; H, 7.17; N, 3.13.

(2S,2'RS)-tert-Butyl 2- $\mathbf{N}$-(9-phenyl-9H-fluoren-9-yl)amino-3-[ $\mathbf{N}$-(2-trimethylsilyl-ethanesulfonyl)aziridin-2'-yl]propanoate (13). To a suspension of activated $3 \AA$ molecular sieves $(3.75$ $\mathrm{g}$ ) in acetonitrile $(25 \mathrm{~mL})$ were successively added compound $\mathbf{1 0}$ (2.39 g, $5.8 \mathrm{mmol})$ and 
$\mathrm{Cu}\left(\mathrm{CH}_{3} \mathrm{CN}\right)_{4} \mathrm{PF}_{6}(0.63 \mathrm{~g}, 0.25$ eq.). A mixture of 2-trimethylsilylethanesulfonamide (1.37 g, 1.3 eq.) and iodosylbenzene 1 ( $1.7 \mathrm{~g}, 1.3$ eq.) was then introduced in five portions over a period of $1.5 \mathrm{~h}$. The reaction mixture was stirred overnight at room temperature then filtered through a pad of Celite and concentrated under reduced pressure. The residue was purified by flash chromatography on silica gel (heptane-ethyl acetate 95:5 then 90:10) to afford the $N$ (Ses)aziridine $13(0.95 \mathrm{~g}, 1.61 \mathrm{mmol}, 28 \%)$ as an inseparable mixture of diastereoisomers. ${ }^{1} \mathrm{H}$ $\mathrm{NMR}\left(\mathrm{CDCl}_{3}, 250 \mathrm{MHz}\right) \delta 0.05(\mathrm{~s}, 6.1 \mathrm{H}), 0.07(\mathrm{~s}, 2.9 \mathrm{H}), 1.05-1.15(\mathrm{~m}, 2 \mathrm{H}), 1.20(\mathrm{~s}, 9 \mathrm{H}), 1.25-$ $1.45(\mathrm{~m}, 2 \mathrm{H}), 1.8-2.05(\mathrm{~m}, 2 \mathrm{H}), 2.4-2.7(\mathrm{~m}, 2 \mathrm{H}), 2.75-3.1(\mathrm{~m}, 3 \mathrm{H}), 7.2-7.45(\mathrm{~m}, 11 \mathrm{H}), 7.65-7.75$ $(\mathrm{m}, 2 \mathrm{H}) ;{ }^{13} \mathrm{C} \mathrm{NMR}\left(\mathrm{CDCl}_{3}, 75 \mathrm{MHz}\right) \delta-1.9,-1.8,9.4,10.0,28.0,32.9,33.6,37.0,37.5,37.9$, $48.7,49.0,54.6,73.2,81.5,119.9,120.1,120.2,125.6,126.2,126.4,127.4,128.0,128.1,128.3$, $128.4,128.5,140.1,141.2,144.5,144.7,148.9,149.2,174.1,174.2$; IR (film) v 1725, 1449, 1323, 1251, 1145, 846, $748 \mathrm{~cm}^{-1}$; ESMS m/z $629.1\left[\mathrm{M}+\mathrm{K}^{+}\right], 612.9\left[\mathrm{M}+\mathrm{Na}^{+}\right], 590.9\left[\mathrm{M}+\mathrm{H}^{+}\right]$. Anal. Calcd for $\mathrm{C}_{33} \mathrm{H}_{42} \mathrm{~N}_{2} \mathrm{O}_{4} \mathrm{SSi}$ : C, 67.07 ; H, 7.16 ; N, 4.74 ; S, 5.43. Found : C, 67.27; H, 7.38; N, $4.56 ; \mathrm{S}, 5.34$.

\section{Acknowledgements}

We thank the MENRT (L.S.) and the Institut de Chimie des Substances Naturelles (L.L.) for fellowships.

\section{References}

1. Willgerodt, C. Chem. Ber. 1892, 25, 3494.

2. Saltzman, H.; Sharefkin, J.G. In Organic Syntheses; Baumgarten, H.C., Ed.; John Wiley \& Sons: New York, 1973; Vol. 5, pp 658-659.

3. Moriarty, R.M.; Kosmeder II, J.W. In Encyclopedia of Reagents for Organic Synthesis; Paquette, L.A., Ed.; John Wiley \& Sons: 1995; Vol. 4, pp 2846-2850.

4. Abramovitch, R.A.; Bailey, T.D.; Takaya, T.; Uma, V. J. Org. Chem. 1974, 39, 340.

5. Yamada, Y.; Yamamoto, T.; Okawara, M. Chem. Lett. 1975, 361.

6. (a) preliminary account : Evans, D.A.; Faul, M.M.; Bilodeau, M.T. J. Org. Chem. 1991, 56, 6744. (b) Evans, D.A.; Faul, M.M.; Bilodeau, M.T. J. Am. Chem. Soc. 1994, 116, 2742.

7. For some representative applications : (a) Hudlicky, T.; Tian, X.; Königsberger, K.; Maurya, R.; Rouden, J.; Fan, B. J. Am. Chem. Soc. 1996, 118, 10752. (b) Masse, C.E.; Knight, B.S.; Stavropoulos, P.; Panek, J.S. J. Am. Chem. Soc. 1997, 119, 6040. (c) Dauban, P.; Dodd, R.H. Tetrahedron Lett. 1998, 39, 5739. (d) Li, L.-S.; Wu, Y.-L.; Wu, Y. Org. Lett. 2000, 2, 891. (e) Di Chenna, P.H.; Dauban, P.; Ghini, A.; Burton, G.; Dodd, R.H. Tetrahedron Lett. 2000, 41, 7041. (f) White, R.D.; Wood, J.L. Org. Lett. 2001, 3, 1825. (g) Sudau, A.; Münch, 
W.; Bats, J.W.; Nubbemeyer, U. Chem. Eur. J. 2001, 7, 611. (h) Caine, D.; O'Brien, P.; Rosser, C.M. Org. Lett. 2002, 4, 1923.

8. Dauban, P.; Sanière, L.; Tarrade, A.; Dodd, R.H. J. Am. Chem. Soc. 2001, 123, 7707.

9. Horii, S.; Kameda, Y. J. Antibiotics 1968, 31, 665.

10. Tsuji, S.; Kusumoto, S.; Shiba, T. Chem. Lett. 1975, 1281.

11. Schricker, B.; Thirring, K.; Berner, H. Bioorg. Med. Chem. Lett. 1992, 2, 387.

12. Dauban, P.; Dodd, R.H. J. Org. Chem. 1999, 64, 5304.

13. Södergren, M.J.; Alonso, D.A.; Bedekar, A.V.; Andersson, P.G. Tetrahedron Lett. 1997, 38, 6897.

14. Rhodium acetate $\mathrm{Rh}_{2}(\mathrm{OAc})_{4}$ was also tested in the aziridination of compound $\mathbf{1 0}$ but the yield was even less satisfactory $(\approx 15 \%)$. For a recent application of rhodium catalyst in aziridination, see: Guthikonda, K.; Du Bois, J. J. Am. Chem. Soc. 2002, 124, 13672.

15. This assumption was made since 3,5-dimethoxybenzaldehyde was isolated at the end of the reaction.

16. We made the assumption that complexation of copper by the resulting $\beta$-amino aziridine could induce a ligand-decelerated catalysis.

17. Evans, D.A.; Faul, M.M.; Bilodeau, M.T.; Anderson, B.A. J. Am. Chem. Soc. 1993, 115, 5328.

18. Yeh, T.-L.; Liao, C.-C.; Uang, B.-J. Tetrahedron 1997, 53, 11141. 